\title{
New insights into the pathogenesis of IgA nephropathy
}

\author{
See Cheng Yeo ${ }^{1}$ Chee Kay Cheung ${ }^{2,3} \cdot$ Jonathan Barratt ${ }^{2,3}$ (D)
}

Received: 31 March 2017 /Revised: 8 May 2017 / Accepted: 11 May 2017 / Published online: 17 June 2017

(C) The Author(s) 2017. This article is an open access publication

\begin{abstract}
IgA nephropathy is the most common form of glomerulonephritis in many parts of the world and remains an important cause of end-stage renal disease. Current evidence suggests that IgA nephropathy is not due to a single pathogenic insult, but rather the result of multiple sequential pathogenic "hits". An abnormally increased level of circulating poorly $O$ galactosylated IgA1 and the production of $O$-glycan-specific antibodies leads to the formation of IgA1-containing immune complexes, and their subsequent mesangial deposition results in inflammation and glomerular injury. While this general framework has formed the foundation of our current understanding of the pathogenesis of IgA nephropathy, much work is ongoing to try to precisely define the genetic, epigenetic, immunological, and molecular basis of IgA nephropathy. In particular, the precise origin of poorly $O$-galactosylated IgA1 and the inciting factors for the production of $O$-glycan-specific antibodies continue to be intensely evaluated. The mechanisms responsible for mesangial IgA1 deposition and subsequent renal injury also remain incompletely understood. In this review, we summarize the current understanding of the key steps involved in the pathogenesis of IgA nephropathy. It is hoped that further advances in our understanding of this common glomerulonephritis will lead to novel diagnostic
\end{abstract}

Jonathan Barratt

jb81@le.ac.uk

1 Department of Renal Medicine, Tan Tock Seng Hospital, Singapore, Singapore

2 Department of Infection, Immunity and Inflammation, University of Leicester, University Road, Leicester LE1 7RH, UK

3 The John Walls Renal Unit, Leicester General Hospital, Leicester, UK and prognostic biomarkers, and targeted therapies to ameliorate disease progression.

Keywords IgA nephropathy $\cdot$ Pathogenesis $\cdot \operatorname{IgA} 1$. $O$-galactosylation $\cdot$ Immune complexes

\section{Introduction}

Since its first description, les dépôts intercapillaires d'IgA$\operatorname{Ig} G$ (intercapillary deposits of $\operatorname{Ig} \mathrm{A}-\operatorname{Ig} \mathrm{G}$ ), by Berger and Hinglais in 1968 [1], IgA nephropathy (IgAN) continues to be recognized as the most common form of glomerulonephritis in many parts of the world [2-6]. While the disease runs a relatively benign course in the majority of patients, up to $40 \%$ of patients progress to end-stage renal disease (ESRD) over the course of 30 to 40 years. Over the past two decades, significant advances have been made in our understanding of the pathogenesis of IgAN. It is now widely accepted that IgAN does not arise from a single pathogenic "hit", but rather arises as a consequence of multiple sequential but distinct pathogenic "hits": principally, an increased level of poorly $O$ galactosylated IgA1 glycoforms, production of $O$-glycan-specific antibodies, and the formation of IgA1-containing immune complexes. The resultant deposition of IgA1containing immune complexes in the glomerular mesangium drives cellular proliferation and overproduction of extracellular matrix, cytokines and chemokines, culminating in glomerular injury. This current concept of the pathogenesis of IgAN has been referred to as the "multi-hit" hypothesis [7].

Much of the work on the pathogenesis of IgAN has centered on understanding the nature of circulating $\operatorname{IgA} 1$ containing immune complexes in IgAN and this has been driven by two key clinical observations. Firstly, IgAN may recur in transplanted kidneys in patients with IgAN, and 
secondly, that clearance of $\operatorname{IgA}$ deposits may occur in transplanted IgAN kidneys that have been inadvertently transplanted into recipients without IgAN [8-10]. These two observations indicate that the initiating pathogenic insult in IgAN must arise outside of the kidney. As we will review below, there are striking changes in the physicochemical properties of circulating IgA1 molecules and development of circulating $O$-glycan-specific antibodies in IgAN, which correlate with the composition of mesangial IgA deposits isolated from glomeruli in IgAN.

Another well-recognized clinical observation is that although mesangial IgA deposition is diffuse and global in IgAN, there is significant heterogeneity in both the pathological response to this deposition, which may be focal and segmental, and the corresponding clinical course. The sole criterion for the diagnosis of IgAN is the presence of dominant or co-dominant IgA deposits in the glomerular mesangium on kidney biopsy. Yet, the marked heterogeneity in clinical presentation, clinical course and pathological changes in IgAN is striking. It has been suggested that this heterogeneity likely reflects the varied influence of genetic and environmental factors on a host of complex pathogenic mechanisms that modulate the disease phenotype in different individuals and populations. An alternative explanation that has been proposed is that IgAN may not be a "single disease" but rather a group of distinct diseases sharing a final common pathway of mesangial IgA deposition [11]. This is an important consideration when reviewing conflicting data within the IgAN field, as it may be that authors are describing different disease processes and responses to treatment in subtly different diseases.

Another observation worthy of consideration ahead of any review of $\operatorname{IgAN}$ is the fact that sub-clinical mesangial $\operatorname{IgA}$ deposition is a relatively common finding in the general population, and in particular in Asian populations. In autopsy series and allograft biopsy series, IgA deposition without overt clinical disease has been observed in up to $16 \%$ of subjects [12-14]. It remains unclear whether these sub-clinical IgA deposits are biochemically different and immunologically inert, or if inherent factors in the affected kidneys prevent the propagation of pathogenic pathways and glomerular injury. Importantly, these observations suggest that the mechanisms responsible for inducing glomerular injury in IgAN are distinct from those responsible for mesangial deposition of IgA. The natural history following the finding of subclinical mesangial IgA deposition, and whether this is a risk factor for overt disease in the long term, remains unclear.

At present, the diagnosis of IgAN cannot be made without a kidney biopsy. The varied clinical course of the disease means that many patients will not develop CKD or progress to ESRD. In order to appropriately counsel patients with IgAN on future risks of CKD and ESRD and direct often toxic immunosuppressive drug regimens to those patients most likely to benefit, early identification of patients at greatest risk of progression is essential. Current clinical markers of severity of kidney disease, namely proteinuria, hypertension, and impaired renal function, are non-specific and manifest only when significant (and often irreversible) renal injury and scarring have occurred. A better understanding of the pathogenesis of IgAN is likely to lead to the identification of novel biomarkers to better risk stratify patients and guide treatment choices. Furthermore, current treatment of IgAN remains generic and applicable to many kidney diseases, focusing on modulating downstream immune and inflammatory events, and is not specific to IgAN. It is hoped that advances in our understanding of the pathogenesis of IgAN will identify new pathways amenable to therapeutic manipulation and in this review we give a number of examples of novel therapies currently in phase II trials that have been triggered by a clearer understanding of the molecular basis of IgAN $[15,16]$. Here, we will review key pathogenic pathways involved in the development of IgAN.

\section{IgA1 $O$-galactosylation in IgA nephropathy}

A key observation in our understanding of the pathogenesis of IgAN is the increased presence of poorly $O$-galactosylated IgA1 glycoforms in both serum and glomerular immune deposits $[17,18]$, a finding that has been consistently reproduced in populations of different ethnic and geographic origin [19-22]. These $O$-glycoforms of IgA1 are often referred to in the literature as galactose-deficient IgA1 (gd-IgA1), however, we believe that this is a misnomer, as most of these $O$ glycoforms still carry galactose residues and "deficiency" implies these $O$-glycoforms have been defectively $O$-glycosylated during post-translational modification. On the contrary, we believe poorly $O$-galactosylated $\operatorname{IgA} 1$ is the normal $O$-glycosylated form of IgA1 produced at mucosal surfaces and its increased presence in the serum reflects a subtle defect in the mucosal immune system.

Human IgA consists of two subclasses: $\operatorname{IgA} 1$ and $\operatorname{IgA} 2$, but only IgA1 is present in the mesangial deposits of IgAN [23]. IgA1 has an 18-amino acid extended hinge region between the first and second constant domains of the $\alpha$ heavy chain where $O$-glycans chains may attach to serine or threonine residues (Fig. 1). Although there are up to nine possible serine/ threonine sites available for $O$-galactosylation in each $\alpha$ heavy chain, only between 3 and 6 sites may be occupied at any time. $O$-galactosylation of the hinge region occurs through a series of stepwise co/post-translational modifications mediated by a group of enzymes. This process is initiated by the addition of $\mathrm{N}$-acetylgalactosamine (GalNAc) via an oxygen atom to a serine or threonine residue on the IgA1-hinge region by the activity of $N$-acetylgalactosaminyl-transferase (GalNAcT2). The $O$ glycan chain may then be extended by galactosylation, where galactose is $\beta 1,3$ linked to GalNAc to form a disaccharide by 


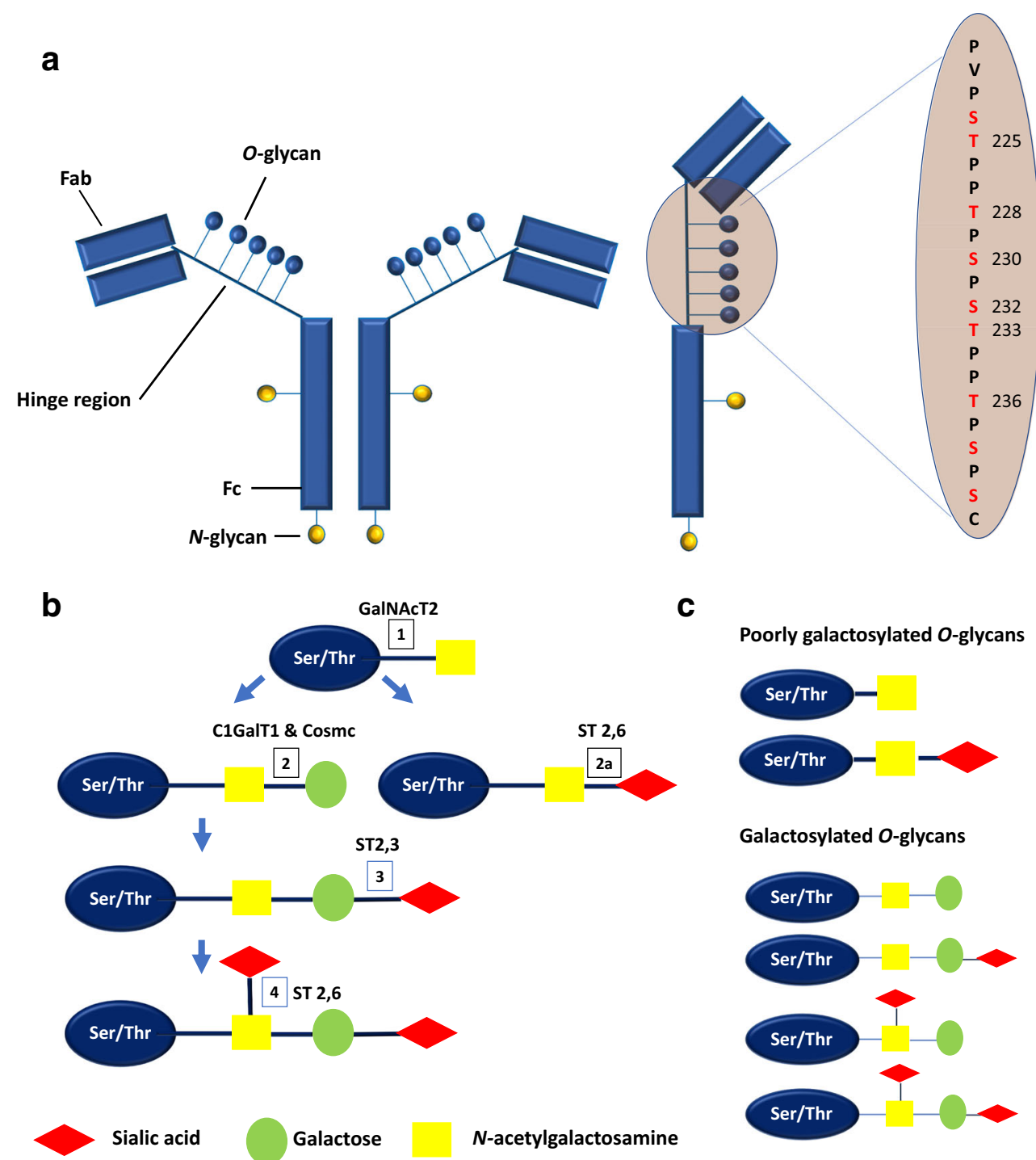

Fig. 1 Structure of human IgA1 and its $O$-glycans. a IgA1 has an extended hinge region that contains between 3 and $6 O$-glycans attached to serine or threonine residue between position 225 to 236 (IgA1 with five $O$-glycans per hinge region is shown). b Glycosylation of IgA1 is mediated by stepwise co-/post-translational modifications. First, $N$-acetylgalactosamine (GalNAc) is added to serine/threonine residue by activity of $N$-acetylgalactosaminyl-transferase (GalNAcT2) (step $1)$. Next, a galactose moiety is added to GalNAc by core 1 beta 1, 3galactosyltransferase $(\mathrm{C} 1 \mathrm{GalT} 1)$ and core $1 \beta 3 \mathrm{GalT}$-specific molecular chaperone (Cosmc) (step 2). Sialic acid may then be added to the

the activity of core 1 beta 1, 3-galactosyltransferase (C1GalT1). Interaction between $\mathrm{C} 1 \mathrm{GalT} 1$ and its molecular chaperone, core $1 \beta 3$ GalT-specific molecular chaperone (Cosmc) is necessary for the stability of C1GalT1 during biosynthesis and to prevent protein misfolding. Sialic acid may be attached to the galactose moiety by $\alpha 2,3$ sialytransferase (ST2,3) or be attached directly to GalNAc in an $\alpha 2,6$ linkage, driven by the activity of $\alpha 2,6$ sialytransferase (ST2,6). It has been proposed that sialylation of GalNAc prevents the further addition of galactose and is therefore an important step in IgA1 $O$-galactosylation $[24,25]$. galactose moiety by $\alpha 2,3$ sialytransferase (ST2,3) (step 3) or to the GalNAc moiety by $\alpha 2,6$ sialytransferase (ST2,6) (step 4). Alternatively, sialic acid may be added to GalNAc by ST2,6 before the addition of galactose (step 2a). Notably, sialylated GalNAc (step 2a) cannot be subsequently galactosylated, whereas galactosylated GalNAc may be sialylated at either the GalNAc or galactose moiety, or both (step 3 and/ or 4). c These steps produce a combination of different $O$-glycoforms of varying degree of galactosylation and sialylation. The relative proportion of poorly galactosylated IgA1 is increased in IgAN

All individuals are capable of synthesizing IgA1 with a range of $O$-galactosylated hinge regions. It has been suggested that we have evolved the ability to alter IgA1 hinge region $O$-glycosylation, in particular to reduce $O$-galactosylation of the $\operatorname{IgA} 1$ hinge, as a way of counteracting the activity of IgA1 proteases released by bacterial pathogens attempting to circumvent the mucosal IgA immune system. Importantly, in health, serum contains poorly $O$ galactosylated $\operatorname{Ig} \mathrm{A} 1$ glycoforms, indistinguishable from those seen in IgAN, however, in IgAN they comprise a greater proportion of the IgA1 $O$-glycoform circulating pool. 
Useful tools for assessing the relative degree of protein glycosylation are lectin-based binding assays (lectins are proteins that bind to specific carbohydrate groups). The most commonly used lectin assay to measure $\operatorname{IgA} 1 O$-galactosylation uses the lectin Helix aspersa agglutinin (HAA), which preferentially binds poorly $O$-galactosylated IgA1 glycoforms (i.e., exposed GalNAc residues). This assay gives a measure of the overall degree of IgA1 $O$-galactosylation in the serum and is determined by the relative amounts of the different $O$-galactosylated IgA1 glycoforms present. Currently, the only way to measure the relative amounts of individual $O$-glycoforms of $\operatorname{IgA} 1$ in serum is to undertake mass spectrometry-based analyses, which while highly informative are not suited to large-scale analysis in IgAN cohorts [26].

A significant drawback to the HAA lectin assay is the variability in stability and bioactivity of HAA between batches (the lectin needs to be isolated from the snail Helix aspersa, and a recombinant form is not available). This has led to difficulties in comparing results across laboratories. Recently, a novel monoclonal antibody with specificity for the poorly $O$-galactosylated hinge region has been developed and this may provide the basis for a robust ELISA, although further validation of the assay will be required in different cohorts [27].

To explain the molecular basis for the existence of different $O$-glycoforms of IgA1, it has been proposed that the expression and/or activity of the required glycosyltransferases is differentially regulated in subpopulations of $\mathrm{IgA} 1$-committed plasma cells. In IgAN, it has been suggested that there might be widespread downregulation of C1GalT1 and/or Cosmc, while others suggest that excessive sialylation of GalNAc by ST2,6 is key in preventing IgA1 $O$-galactosylation [24, 28-30]. It is, however, highly unlikely that a generic defect in $O$-glycosylation of all IgA1 molecules underlies the shift in the complement of serum IgA1 $O$-glycoforms in IgAN. Importantly, $O$-galactosylation of serum IgD (which is also heavily $O$-galactosylated in humans) is not altered in patients with IgAN, suggesting that the decreased $O$-galactosylation of IgA1 in IgAN is not a consequence of an inherent generalized defect of expression or function of galactosylation enzymes in all B cells [31].

A pivotal role for circulating poorly $O$-galactosylated $\operatorname{IgA} 1$ in the pathogenesis of IgAN is supported by two studies that showed that the IgA eluted from mesangial deposits was enriched for poorly $O$-galactosylated IgA1 glycoforms [18, $20]$. Furthermore, higher serum levels of poorly $O$ galactosylated IgA1 have been shown to be associated with disease progression in IgAN [32].

\section{Genetic control of IgA1 $O$-galactosylation}

There is convincing evidence that genetic factors play a major role in influencing the composition of circulating $\operatorname{IgA} 1 O$ glycoforms in serum. Up to half of asymptomatic first- degree relatives of patients with both familial and sporadic IgAN have been found to have high levels of poorly $O$ galactosylated IgA1. Studies of familial IgAN cohorts have previously estimated the heritability of poorly $O$ galactosylated $\operatorname{IgA} 1$ to be between 54 and $76 \%$, and in a recent study of healthy monozygotic and dizygotic twin pairs using the classic twin model, the hereditability of poorly $O$ galactosylated IgA1 was found to be as high as $80 \%$ [33-37]. In contrast, the same studies demonstrated that serum total IgA levels had low heritability, demonstrating that $O$ galactosylation of IgA1 is independent of serum IgA level. In a recently published study, serum levels of poorly $O$ galactosylated IgA1 were found to be associated with a noncoding region of C1GALT1, the gene responsible for encoding the C1GalT1 galactosyltransferase. An association with a noncoding region of the gene is consistent with changes in regulation of ClGALT1, perhaps in specific microenvironments such as the mucosa, rather than a generic change in the structure of C1GalT1 galactosyltransferase affecting all cells. This association was not restricted to IgAN but was also found in healthy subjects and cases of membranous nephropathy, in both white and Chinese populations, supporting the view that circulating levels of poorly $O$-galactosylated IgA1 are heritable and influenced by genetic variation within the C1GALT1 gene [38]. These findings have been replicated in a separate cohort [39]. Interestingly, given that IgAN is more prevalent in Chinese compared to white populations, levels of circulating poorly $O$-galactosylated IgA1 in Chinese IgAN cases were lower than in white IgAN cases and indeed were comparable to that seen in a healthy white population, and this corresponded with the low frequency of the identified ClGALT1 risk haplotype in the Chinese population. This observation raises questions on the pathogenic importance of changes in IgA1 $O$-galactosylation in different ethnic populations, and whether other pathogenetic mechanisms also act at variable levels.

Epigenetic control of IgA1 $\mathrm{O}$-galactosylation is also thought to be important in IgAN. MicroRNAs (miRNA) are endogenous short, noncoding single-stranded RNA molecules that regulate gene expression. Upregulation and overexpression of a specific miRNA (miR-148b) in peripheral blood mononuclear cells (PBMCs) has been associated with a decreased expression of $\mathrm{C} 1 \mathrm{GalT} 1$ and production of poorly $O$ galactosylated IgA1. Intriguingly, a binding site for miR-148b has been identified within the recently identified C1GALT1 risk haplotype (1365G > A polymorphism or rs1047763) supporting further a role for miR-148b in IgAN [40].

\section{The origin of poorly $O$-galactosylated IgA1 in IgAN}

Recognizing that poorly $O$-galactosylated IgA 1 plays a pivotal role in the pathogenesis of IgAN, the origin of the 
responsible $\mathrm{B} /$ plasma cells has been the subject of intensive study. The current belief is that the originating B cells undergo activation and programming in the mucosal immune system, however, a significant proportion of the resultant plasma cells eventually reside in the bone marrow rather than in the mucosa, possibly due to defective trafficking during B cell maturation.

There are numerous lines of evidence supporting the mucosal immune system as the source of poorly $O$-galactosylated IgA1-secreting B/plasma cells. Clinically, patients with IgAN not infrequently develop visible hematuria after an upper respiratory tract infection (termed synpharyngitic hematuria) and this is associated with an increase in circulating $\operatorname{IgA}$ immune complex levels [41]. Mucosal IgA, unlike systemic IgA, is typically polymeric, of low affinity, and relatively poorly $O$ galactosylated, the physicochemical characteristics typically observed in serum and mesangial $\operatorname{IgA}$ in $\operatorname{IgAN}[42,43]$. IgAN has also been associated with diseases in which mucosal immune responses are abnormal, such as coeliac disease and inflammatory bowel disease. Significantly, recent genomewide association studies in IgAN have identified susceptibility loci in genes involved in intestinal mucosal immunity [44].

While the importance of the mucosal-kidney axis in IgAN is being increasingly recognized, it remains unclear how alterations in the mucosal immune system lead to an increase in the complement of poorly $O$-galactosylated IgA 1 glycoforms in the serum in IgAN. The majority of circulating IgA1 is monomeric, heavily $O$-galactosylated and derived from bone marrow-residing plasma cells. In contrast, mucosally residing plasma cells synthesize IgA1 that is predominantly polymeric, poorly $O$-galactosylated, and secreted onto mucosal surfaces, with little, if any normally entering the circulation. It has been postulated that the increase in poorly $O$-galactosylated serum IgA1 glycoforms in IgAN is the result of misdirected secretion of "mucosal IgA" into the circulation, rather than onto mucosal surfaces. Intriguingly, the numbers of plasma cells that secrete "mucosal IgA" are reduced in the mucosa but numbers are increased at systemic sites, in particular the bone marrow in IgAN $[45,46]$. It has therefore been suggested that this misdirected secretion of "mucosal IgA" into the circulation is the result of mucosal-derived B/plasma cells that have mistrafficked to the bone marrow instead of homing back to mucosal surfaces, resulting in release of "mucosal IgA" directly into the systemic circulation. While there is some evidence for defective homing receptor expression by lymphocytes in IgAN, much more work is required to define precisely the pattern of B cell trafficking in IgAN [47-50].

\section{Dysregulated mucosal IgA production in IgAN}

In parallel with the potential mistrafficking of mucosal B/ plasma cells, there is also evidence of a subtly dysregulated mucosal immune response to antigen in IgAN. A number of studies have examined immune responses to mucosal antigen challenge in IgAN and the majority have reported exaggerated systemic IgA responses to mucosal antigen challenge [51-56]. There has been increasing interest examining links between alterations in gut permeability, the gut microbiome, and interaction with the mucosal immune system in IgAN, and these studies have recently been reviewed $[57,58]$. One mucosal antigen that has attracted particular attention is gliadin, a component of gluten. Mice subjected to a gluten-free diet from birth, and then exposed to a gluten-rich diet, developed increased IgA deposition, with anti-gliadin IgA found in the serum and glomerular deposit eluates [59]. Furthermore, in a recently developed transgenic mouse model that expresses both human IgA1 and human CD89, and develops IgAN spontaneously, in those fed a gluten-free diet for three generations, there was a reduction in mesangial IgA deposition and glomerular inflammatory cell infiltration [60]. Exposure of these mice to gluten led to increased mesangial IgA deposition and formation of anti-gliadin IgA. In a clinical study of IgAN patients given a gluten-free diet, reductions in hematuria, proteinuria, IgA immune complex formation, and anti-gliadin IgA were observed, but there was no difference in the rate of decline in renal function over 4 years of follow-up [61]. Further studies regarding potential links between dietary antigens and $\operatorname{IgA}$ immune complex formation are needed.

The molecular basis of regulation of the mucosal immune response, and in particular mucosal B cell programming, in health, and IgAN are complex. Two events thought to be critical are antigen-driven activation of the innate immune response, in particular through ligation of Toll-like receptors (TLR), and B-cell activating factor (BAFF) and a proliferation inducing ligand (APRIL) signaling [62].

TLRs represent an important part of the early innate immune response to invading microbial pathogens and endogenous danger signals via recognition of a diverse range of pathogen-associated molecular patterns (PAMPs) and danger-associated molecular patterns (DAMPs), such as bacterial lipopolysaccharide (LPS), RNAs, and DNAs [63, 64]. TLRs can be found on a diverse range of cells including macrophages and dendritic cells, and the stimulation of TLRs initiates signaling cascades that result in a variety of cellular responses including the production of interferons (IFNs), and pro-inflammatory and effector cytokines that direct the adaptive immune response. B cells also express a variety of TLRs and specifically TLR-4, -9 and -10 have been implicated in IgAN $[62,65,66]$. Expression of mRNA for TLR-4 in circulating PBMCs is increased in children with IgAN and HSP compared to healthy subjects [67]. Exposure to environmental antigens results in an elevated level of TLR- 9 and more severe IgA-mediated injury in a murine IgAN model [62], and stimulation of mucosal lamina propria B cells by a TLR-9 ligand containing the $\mathrm{CpG}$-oligodeoxynucleotide (CpG-ODN) 
bacterial DNA motif induces IgA production [68]. Besides driving mucosal IgA production, TLR activation can also modify glycosyltransferase activity through methylation of the Cosmc gene resulting in reduced activity of C1GalT1, favoring production of poorly $O$-galactosylated $\operatorname{IgA} 1[66,69]$.

BAFF is necessary for B-cell maturation and survival, and levels of BAFF are elevated in many autoimmune diseases and correlate with autoantibody concentration [70-74]. Mice that overexpress BAFF have raised levels of polymeric IgA, and evidence of mesangial IgA deposition [75]. Importantly, this $\operatorname{IgA}$ deposition is dependent on activation of the mucosal immune system. In human IgAN, serum BAFF levels are elevated, and are associated with worse renal histopathologic injury (increased mesangial hypercellularity, segmental glomerulosclerosis, and tubular atrophy/interstitial fibrosis) and higher serum creatinine [76]. Tonsillar mononuclear cells (TMCs), which are part of the mucosal-associated lymphoid tissue of Waldeyer's ring, from IgAN patients exposed to CpG-ODN produce high levels of BAFF and IgA, and this production of IgA can be inhibited by blockade of BAFF signaling [77]. APRIL, another member of the tumor necrosis factor ligand superfamily (TNFSF), which shares common receptors with BAFF, also plays an important role in $\mathrm{B}$ cell maturation and survival, and is involved in generation of $\operatorname{IgA-}$ secreting plasma cells. Genome-wide association studies in IgAN have identified TNFSF13 (which encodes APRIL) as a susceptibility locus [78], and this risk variant is associated with high serum levels of IgA in patients with IgAN. Zhai et al. showed that increased levels of APRIL were associated with increased levels of poorly $O$-galactosylated $\operatorname{IgA} 1$ and a more severe clinical presentation [69]. In a recent study, Muto et al. demonstrated that tonsillar TLR9 and APRIL levels were elevated and correlated with one another in IgAN, and that TLR-9 stimulation induced APRIL expression in tonsillar B cells [79].

\section{Therapeutic manipulation of the mucosal immune system and BAFF/APRIL signaling in IgAN}

Taken together, available data suggests that mucosal programming of B cells in IgAN, involving TLRs and BAFF/APRIL, plays a critical role in the development of IgAN. There has, not surprisingly, been great interest in targeting these pathways in IgAN using novel immunomodulatory strategies (Fig. 2) [16].

The NEFIGAN study evaluated targeted immunosuppression of the mucosal immune system using enteric budesonide [80]. This formulation of budesonide is a modified release formulation, designed specifically to deliver budesonide to the ileocecal Peyer's patches, with minimal systemic exposure and side effects due to first-pass metabolism. In this study, a significant reduction in proteinuria was observed following
9 months of treatment supporting the hypothesis that the mucosal immune system plays an important role in IgAN.

In contrast to targeted mucosal immunomodulation, systemic B cell depletion with rituximab is not effective in IgAN, reinforcing the importance of the mucosal immune system in the pathogenesis of IgAN. In a small open-label randomized controlled trial use of rituximab compared to conventional therapy (without immunosuppression), resulted in more adverse events, did not significantly improve renal function or proteinuria over 1 year and did not reduce serum levels of poorly O-galactosylated IgA1 or anti-IgA1 IgG autoantibodies, despite effective circulating B cell depletion [81].

Blisibimod and atacicept are currently being evaluated in separate phase II studies in IgAN. Both agents target the BAFF and APRIL signaling pathways. Blisibimod is a selective peptibody antagonist of BAFF. Atacicept is a fusion protein containing the extra-cellular, ligand-binding portion of TACI (one of the receptors for BAFF and APRIL) and the modified $\mathrm{Fc}$ portion of human $\mathrm{IgG}$, and acts by blocking BAFF and APRIL. Preliminary results from the BRIGHTSC study, a phase 2, randomized, double-blind, placebocontrolled trial, suggest that subcutaneous blisibimod may prevent worsening of proteinuria in IgAN (ClinicalTrials.gov Identifier: NCT02062684).

Hydroxychloroquine is a potent inhibitor of TLR-9, and to a lesser extent TLR-7 and TLR-8, and inhibits antigen processing and presentation via alkalinization of proteasomes $[82,83]$. Given the proposed role of TLRs in the pathogenesis of IgAN, a small paired case-control study has been conducted which described benefit in terms of reduction in proteinuria in treated IgAN patients at 24 weeks follow-up [84]. Further validation in larger randomized studies with longer-term follow-up will be required.

\section{$O$-glycan-specific autoantibodies and circulating immune complex formation in IgAN}

As already eluded to, while the presence of poorly $O$ galactosylated IgA1 is a key observation in IgAN, this finding alone is not sufficient for the development of clinical disease. In in vitro experiments utilizing IgA1 isolated from patients with IgA myeloma, human mesangial cells can be activated by the presence of poorly $O$-galactosylated polymeric IgA1 and IgG/A immune complexes but not by monomeric IgA1 alone [85]. It has therefore been proposed that the formation of circulating immune complexes, perhaps triggered by $O$-glycanspecific antibodies, is necessary for the development of the glomerular injury, and that poorly $O$-galactosylated IgA1 molecules are the substrate for the formation of these immune complexes (Fig. 3). The frequent observation of co-deposits of $\operatorname{IgG}$ and occasionally $\operatorname{IgM}$ with $\operatorname{IgA}$ in the mesangium in IgAN supports the generation of mixed immune complexes in 


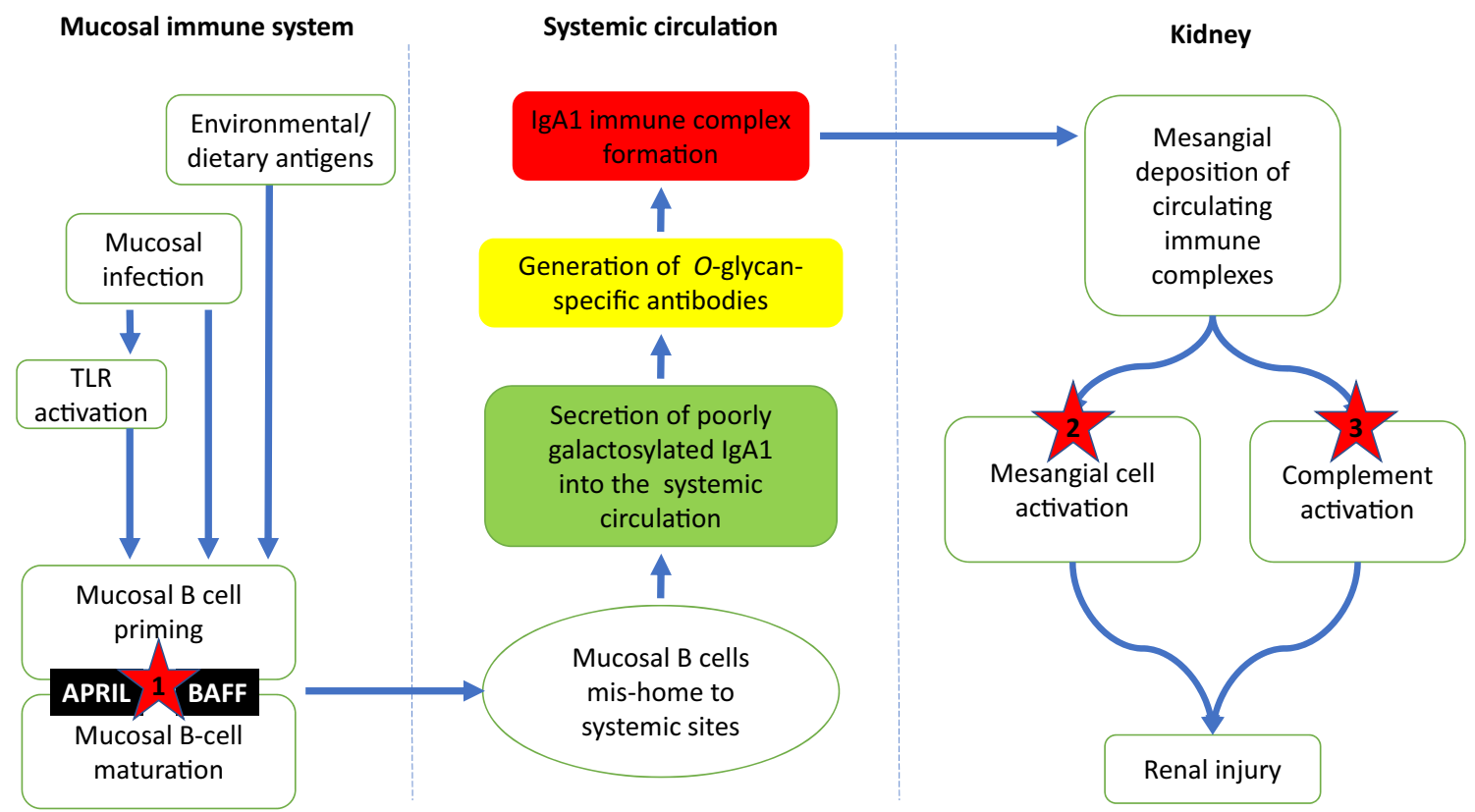

Fig. 2 A proposed pathogenic model for IgAN with a focus on potential therapeutic targets. In this model, a dysregulated mucosal immune system results in excessive mucosal IgA-committed B cell proliferation in response to mucosal antigen exposure, mediated in part through excessive BAFF and APRIL signaling. As a result of mis-homing of a proportion of these mucosal B cells to systemic sites mucosal IgA is secreted directly into the circulation resulting in elevated serum levels of polymeric, poorly galactosylated IgA1. In susceptible individuals, $O$-glycan-specific

IgAN [86-88]. Serum levels of $O$-glycan-specific antibodies are associated with disease activity and progressive kidney disease, further supporting the role of $O$-glycan-specific antibodies in the pathogenesis of IgAN $[89,90]$. It has recently been reported that $O$-glycan-specific IgG antibodies in IgAN contain a specific amino acid sequence, Y1CS3, in the heavy chain variable region, compared with a Y1CA3 sequence in isotype-matched $\mathrm{IgG}$ from healthy controls, that the $\mathrm{S} 3$ residue is critical for binding to poorly $O$-galactosylated $\operatorname{IgA} 1$, and that this substitution is not observed in germline DNA and appears to be a result of a somatic mutation, perhaps influenced by exposure to specific environmental antigens $[86,91]$.

It has been hypothesized that changes in $O$-galactosylation of the IgA1-hinge region could result in conformational change of the molecule and exposure of novel epitopes within the hinge region. These novel epitopes may then trigger specific $O$-glycan-specific autoantibody production, and/or be recognized by serum antimicrobial antibodies that mistake the IgA1 hinge region $O$-glycans for bacterial or viral cell wall glycoprotein structures (molecular mimicry). One intriguing possibility is that during mucosal infections it is the increased production of antimicrobial mucosal antibodies that heightens the serum $O$-glycan-specific immunoreactivity and drives immune complex formation in $\operatorname{IgAN}$, resulting in a temporary flooding of the glomeruli with $\operatorname{IgA}$ immune complexes and antibodies are formed with the consequent generation of circulating $\operatorname{IgA}$ immune complexes, which have a propensity for mesangial deposition. Glomerular accumulation of these IgA immune complexes results in mesangial cell activation, and release of pro-inflammatory and profibrotic mediators, and complement activation. Within this model, there are a number of potential targets (denoted by *) for novel therapeutic agents, many of which are currently under evaluation in clinical trials in IgAN

short-lived severe glomerular inflammation with development of synpharyngitic hematuria. It is also possible that antimicrobial mucosal antibodies generated at the time of a mucosal infection include poorly galactosylated $\operatorname{IgA} 1$, contributing further to both the pool of the target protein and $O$-glycan-specific antibodies in IgAN (Fig. 3).

In support of a pathogenic role for $O$-glycan-specific autoantibody production in IgAN, the strongest signal in genomewide association studies in IgAN localizes to susceptibility loci on chromosome $6 \mathrm{p}$ within the human leucocyte antigen region. These loci are important in determining antigenprocessing and presentation, and this association suggests that a dysregulated adaptive immune response may play a role in preferentially presenting poorly $O$-galactosylated $\operatorname{IgA} 1$ as a self-antigen and in the permissive production of $O$-glycanspecific antibodies in IgAN [44, 92].

\section{Soluble CD89 and circulating immune complexes}

Another proposed explanation for the excessive formation of IgA1-containing immune complexes is an abnormal interaction between circulating $\operatorname{IgA} 1$ and the myeloid $\operatorname{IgA}$ receptor CD89 in IgAN [93]. CD89 is an Fc $\alpha$ receptor and exists in membrane-bound and soluble (sCD89) forms. Two isoforms of sCD89 have been described in vivo with the smaller 


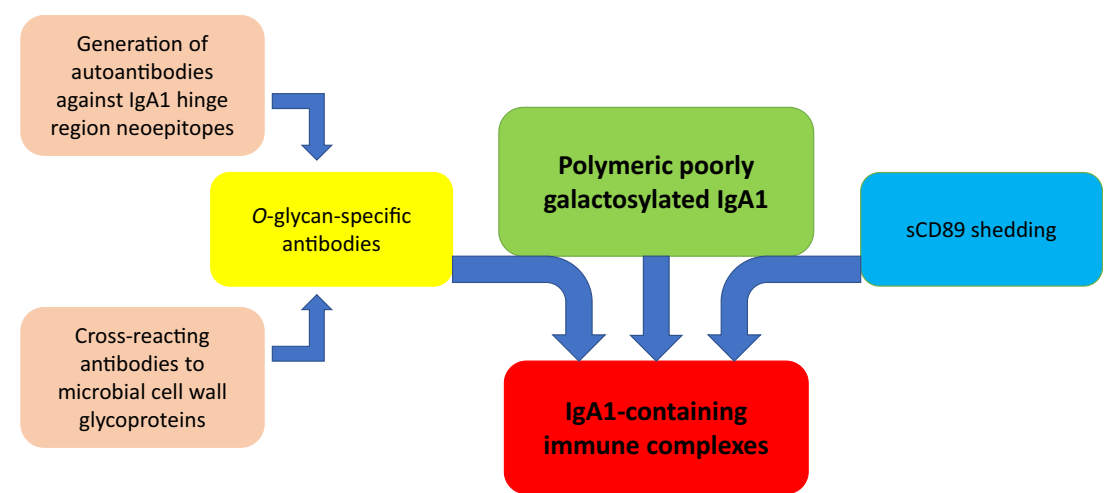

Fig. 3 Formation of circulating IgA-immune complexes in IgA nephropathy. Polymeric poorly galactosylated IgA1 molecules form the substrate for immune complex formation. $O$-glycan-specific antibodies: either IgG and IgA1 autoantibodies, or cross-reacting anti-microbial antibodies, bind to the exposed neo-epitopes within the poorly galactosylated IgA1 hinge region. An alternative hypothesis for the formation of circulating $\operatorname{IgA}$ immune complexes is that soluble CD89 (sCD89) is shed from myeloid cells in response to polymeric IgA1, and form large circulating IgA1sCD89 immune complexes

to the histopathological features identified in the Oxford classification, which are independent predictors of developing progressive renal disease in IgAN, namely mesangial hypercellularity (M), endocapillary hypercellularity (E), segmental glomerulosclerosis (S), and tubular atrophy/interstitial fibrosis (T), and as recently reported in an update to the original classification, glomerular crescent formation (C) [103, 104]. Mesangial cell IgA binding triggers the release of proinflammatory and chemotactic mediators, which act locally in the glomerulus, leading to mesangial cell proliferation (M) and recruitment of inflammatory cells into the glomerulus (E), occasionally resulting in crescent formation (C). These mediators also, in turn, alter podocyte gene expression and glomerular permeability, causing filtration of IgA immune complexes, podocyte damage (glomerulopodocytic crosstalk), and segmental glomerulosclerosis (S) [105-108]. In addition to effects within the glomerulus, glomerular-derived cytokines, along with filtered $\mathrm{pIgA1}$, are capable of activating proximal tubule epithelial cells (glomerulotubular crosstalk), driving tubulointerstitial fibrosis (T) [109].

Recognition of mesangial IgA deposits by resident glomerular cells is incompletely understood. The best-characterized receptor for mesangial IgA is the transferrin receptor (CD71), which is expressed by mesangial cells. CD71 is a multi-ligand receptor that has been shown to bind polymeric IgA1 [110]. CD71 is overexpressed on the surface of proliferating human mesangial cells in IgAN, and co-localization of CD71 with IgA1 immune deposits has been demonstrated in kidney biopsies [111]. Furthermore, the binding of poorly $O$-galactosylated IgA1 to CD71 appears to further enhance the expression of CD71 on proliferating mesangial cells, creating an autoamplification loop for self-perpetuating glomerular injury [112]. It has been proposed that IgA binding to CD71 in IgAN also involves CD89, in that IgA1-sCD89 complexes are capable of binding to CD71 and activating mesangial cells [113]. However, glomerular deposition of CD89 has not been 


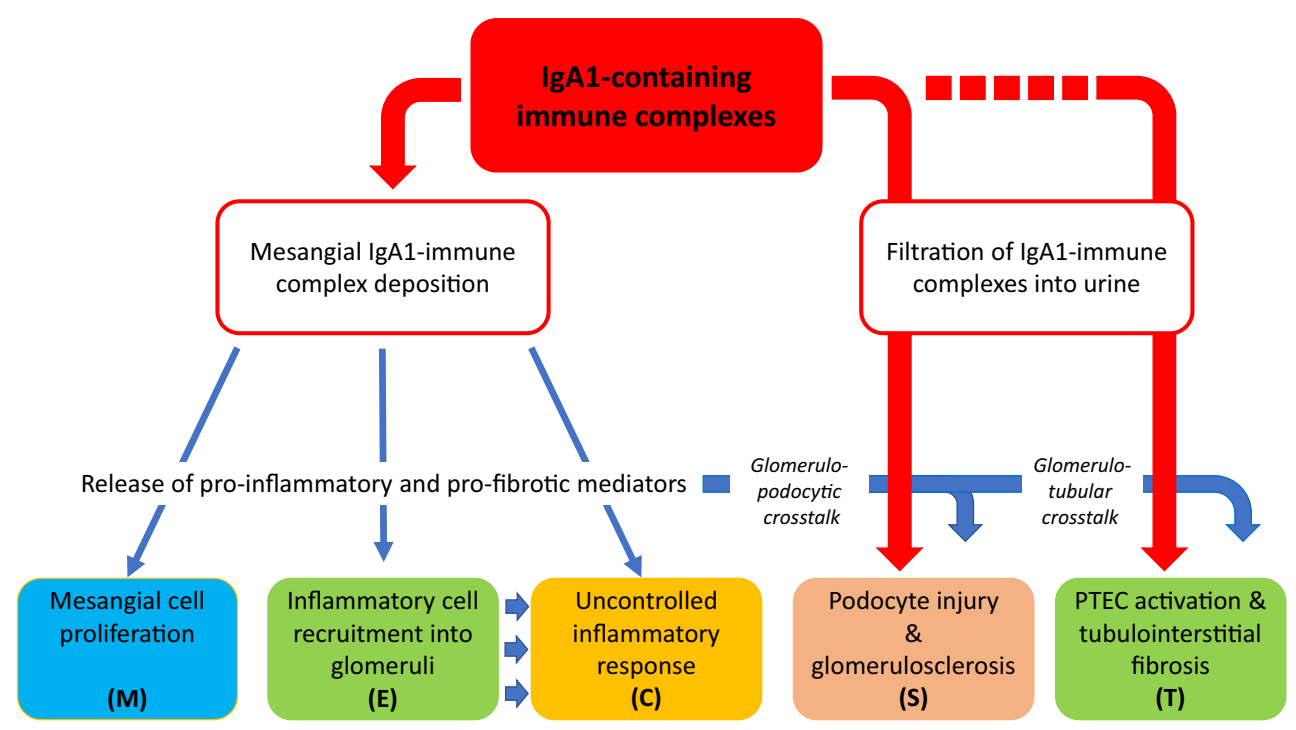

Fig. 4 Pathological consequences of IgA immune complex deposition in IgAN. IgA1 immune complexes deposit in the mesangium and trigger mesangial cell activation, resulting in release of pro-inflammatory, chemotactic, and pro-fibrotic mediators. Released soluble mediators result in mesangial cell proliferation, extracellular matrix (ECM) synthesis, recruitment of inflammatory cells, and in severe cases, glomerular crescent formation. Filtered mesangial cell-derived mediators cause podocyte damage (glomerulopodocytic crosstalk) and with damage to the permselective glomerular basement membrane filtered IgA immune

conclusively demonstrated in IgAN. Importantly, there is strong evidence that CD71 is not the only mesangial cell IgA receptor, however, none of the other well-characterized IgA receptors, including CD89, polymeric immunoglobulin receptor, and the hepatic asialoglycoprotein receptor, are expressed by human mesangial cells in health or in $\operatorname{IgAN}$ and the nature of this receptor(s) is not known [114].

Most studies examining renal injury in IgAN have focused on the effects of IgA on mesangial cell biology, however, with damage to the glomerular basement membrane, there is emerging evidence that $\operatorname{IgA}$ immune complexes can enter the urine and directly interact with other cells within the nephron [115]. Data supports a direct interaction between filtered IgA immune complexes and podocytes and proximal tubule epithelial cells $[105,109]$, resulting in podocyte injury and loss, and epithelialmesenchymal transformation with consequent tubulointerstitial scarring, respectively. These effects appear to be specific to $\operatorname{IgA}$ immune complexes generated in IgAN and may be related, at least in part, to the poorly $O$-galactosylated hinge region of the IgA1 molecule. Understanding how filtered IgA immune complexes interact with podocytes and proximal tubule epithelial cells may help us understand why some patients with IgAN have mesangial deposition only, while others display marked podocyte injury and tubulointerstitial scarring, and why the degree of mesangial deposition does not correlate with the severity of ensuing renal inflammation and injury.

With the advent of a plethora of tyrosine kinase inhibitors, there is increasing interest in defining the intracellular complexes compound podocyte injury. Filtered mesangial cell-derived mediators and IgA immune complexes are also capable of injuring proximal tubule epithelial cells (PTECs), promoting tubulointerstitial inflammation and scarring (glomerulotubular crosstalk). These pathogenic processes result in mesangial hypercellularity (M), endocapillary hypercellularity (E), segmental glomerulosclerosis (S), tubular atrophy/ interstitial fibrosis $(\mathrm{T})$, and crescent formation $(\mathrm{C})$, pathological features that define the Oxford classification and have been shown to be independent predictors of outcome in IgAN

biochemical pathways activated by IgA immune complexes in the kidney in IgAN. Spleen tyrosine kinase (Syk) signaling is of particular interest in IgAN as it is not only active in mesangial and proximal tubule epithelial cells but is also involved in immunoreceptor signaling in B cells and immunoglobulin production. Glomerular Syk phosphorylation is increased in rodent models of proliferative glomerulonephritis and correlates with serum creatinine and histological features of disease activity [116]. Inhibiting Syk signaling reduces pro-inflammatory cytokine production, tissue inflammation and damage in both in vivo and in vitro models of kidney injury [117, 118]. Kim et al. demonstrated a clear upregulation of glomerular phospho-Syk levels in IgAN [119]. In parallel, Syk inhibition was able to reduce the proliferative and pro-inflammatory effects of IgA immune complexes on mesangial cells in vitro, supporting the testing of Syk inhibition as a treatment for IgAN. SIGN (Syk Inhibitor in GlomeruloNephritis) is a currently open phase 2 randomized, double-blind, placebo-controlled trial that is examining the efficacy of fostamatinib, an oral selective Syk inhibitor, in IgAN (ClinicalTrials.gov Identifier: NCT02112838).

\section{The complement system in IgAN}

There is strong evidence that glomerular injury in IgAN is associated with activation of the complement system [120]. Glomerular deposition of complement component 3 (C3) is commonly observed in kidney biopsies in the same 
distribution as IgA. The presence of $\mathrm{C} 3$, coupled with the near ubiquitous absence of $\mathrm{Cl}$, is consistent with activation of the lectin and/or alternative pathways. Non-classical pathway complement activation is supported by the glomerular deposition of alternative pathway (properdin and factor H) [121, $122]$ and lectin pathway (mannan-binding lectin (MBL), MBL-associated serine proteases 1 and 2, and C4d) [123-125] components in IgAN. Furthermore, the presence of lectin pathway components C4d [126-128] and MBL [129] have been associated with increased disease activity and subsequent development of ESRD.

Genome-wide association studies in IgAN have identified a protective locus at chromosome 1q32 corresponding to deletion of CFHR3,1 (CFHR3,1 $\Delta$ ). CFHR3,1 encodes complement factor H-related proteins 3 and 1, regulatory proteins that compete with factor $\mathrm{H}$ for the binding of $\mathrm{C} 3 \mathrm{~b}$. CFHR3,1 leads to uninhibited binding of $\mathrm{C} 3 \mathrm{~b}$ by factor $\mathrm{H}$ and more effective inhibition of the alternative pathway, hence providing a protective effect against alternative pathway activation in IgAN. Indeed, $C F H R 3,1 \triangle$ has been associated with higher levels of circulating complement factor $\mathrm{H}$ and a reduced level of complement activation split product $\mathrm{C} 3 \mathrm{a}$ [130]. In addition, levels of circulating $\mathrm{CFH}$ correlate positively with circulating C3 levels and negatively with mesangial C3 deposition [130]. Histopathologically, $C F H R 3,1 \Delta$ is associated with reduced tubulointerstitial injury according to the Oxford classification criteria [131]. However, the precise molecular mechanism for this intriguing association in IgAN remains to be elucidated. A variable frequency of $C F H R 3,1 \Delta$ with opposing effects on different immune-complex associated diseases (CFHR3,1 $\Delta$ is also protective against age-related macular degeneration but increases susceptibility to systemic lupus erythematosus and atypical hemolytic uremic syndrome) suggests that balancing selection exists in the expression of this allele, a hypothesis that remains to be tested.

Given the convincing evidence for complement activation in IgAN and the emerging availability of agents that selectively block complement activation, investigators are beginning to explore the utility of complement inhibition in IgAN. Eculizumab, a recombinant, fully humanized hybrid $\mathrm{IgG}_{2}$ / IgG4 monoclonal antibody against complement $\mathrm{C} 5$, prevents the formation of membrane attack complex and has been shown to be effective in atypical hemolytic uremic syndrome and $\mathrm{C} 3$ glomerulopathy, glomerular diseases resulting from dysregulation of the complement system. There have been two case reports of eculizumab use in rapidly progressive IgAN. In both cases, eculizumab was associated with temporary benefit in stabilizing renal function or proteinuria, but in both cases, there was significant disease progression once eculizumab was discontinued $[132,133]$. These case reports raise the possibility of complement inhibition as a potential future treatment strategy in IgAN. One agent under development is OMS721, a monoclonal antibody targeting mannan- binding lectin-associated serine protease-2 (MASP-2), the effector enzyme of the lectin complement pathway. Early data in IgAN suggest that OMS721, and inhibition of the lectin pathway, reduces proteinuria in IgAN. Further data are keenly awaited.

\section{Conclusions}

There has been significant progress in our understanding of IgAN over the past decade, and key pathogenic changes have been identified. Central to our current understanding of the pathogenesis of IgAN is a greater awareness of the importance of IgA immune complexes and the role poorly $O$ galactosylated IgA1 and $O$-glycan-specific antibodies play in their formation. Mesangial immune complex deposition leads to mesangial cell proliferation and production of mesangialderived mediators that drive podocyte and tubulointerstitial injury via mesangial-podocyte-tubular crosstalk. Critical questions, however, remain unanswered - the precise origins of poorly $O$-galactosylated IgA 1 and $O$-glycan-specific antibodies are incompletely understood, as are the factors and mechanisms determining the nephritogenic potential of IgA1-containing immune complexes. Further advances in our understanding of the pathogenesis of IgAN will be crucial in the development of diagnostic and prognostic markers, and novel therapeutics to ameliorate disease progression.

\section{Compliance with ethical standards}

Potential conflict of interest $\mathrm{J}$ Barratt has received research grants from Anthera Pharmaceuticals Inc. and Pharmalink AB. J Barratt acts as a consultant to Pharmalink AB, EMD Serono Inc., Anthera Pharmaceuticals Inc., Omeros Corporation, Kancera AB and Retophin, Inc. CK Cheung and SC Yeo have no conflicts of interest.

Open Access This article is distributed under the terms of the Creative Commons Attribution 4.0 International License (http:// creativecommons.org/licenses/by/4.0/), which permits unrestricted use, distribution, and reproduction in any medium, provided you give appropriate credit to the original author(s) and the source, provide a link to the Creative Commons license, and indicate if changes were made.

\section{References}

1. Berger J, Hinglais N (1968) Intercapillary deposits of IgA-IgG. J Urol Nephrol (Paris) 74:694-695

2. Wyatt RJ, Julian BA (2013) IgA nephropathy. N Engl J Med 368: 2402-2414

3. D'Amico G (2004) Natural history of idiopathic IgA nephropathy and factors predictive of disease outcome. Semin Nephrol 24:179196

4. Le W, Liang S, Hu Y, Deng K, Bao H, Zeng C, Liu Z (2012) Long-term renal survival and related risk factors in patients with IgA nephropathy: results from a cohort of 1155 cases in a Chinese adult population. Nephrol Dial Transplant 27:1479-1485 
5. Zuo L, Wang M, Chinese Association of Blood Purification Management of Chinese Hospital A (2010) Current burden and probable increasing incidence of ESRD in China. Clin Nephrol 74(Suppl 1):S20-S22

6. Barratt J, Feehally J (2005) IgA nephropathy. J Am Soc Nephrol 16:2088-2097

7. Suzuki H, Kiryluk K, Novak J, Moldoveanu Z, Herr AB, Renfrow MB, Wyatt RJ, Scolari F, Mestecky J, Gharavi AG, Julian BA (2011) The pathophysiology of IgA nephropathy. J Am Soc Nephrol 22:1795-1803

8. Berger J, Yaneva H, Nabarra B, Barbanel C (1975) Recurrence of mesangial deposition of IgA after renal transplantation. Kidney Int 7:232-241

9. Floege J (2004) Recurrent IgA nephropathy after renal transplantation. Semin Nephrol 24:287-291

10. Silva FG, Chander P, Pirani CL, Hardy MA (1982) Disappearance of glomerular mesangial IgA deposits after renal allograft transplantation. Transplantation 33:241-246

11. Cheung CK, Barratt J (2015) Is IgA nephropathy a single disease? In: Tomino Y (ed) Pathogenesis and treatment in IgA nephropathy. Springer, Japan, pp 3-17

12. Waldherr R, Rambausek M, Duncker WD, Ritz E (1989) Frequency of mesangial IgA deposits in a non-selected autopsy series. Nephrol Dial Transplant 4:943-946

13. Varis J, Rantala I, Pasternack A, Oksa H, Jantti M, Paunu ES, Pirhonen R (1993) Immunoglobulin and complement deposition in glomeruli of 756 subjects who had committed suicide or met with a violent death. J Clin Pathol 46:607-610

14. Suzuki K, Honda K, Tanabe K, Toma H, Nihei H, Yamaguchi Y (2003) Incidence of latent mesangial IgA deposition in renal allograft donors in Japan. Kidney Int 63:2286-2294

15. Coppo R (2017) Biomarkers and targeted new therapies for IgA nephropathy. Pediatr Nephrol 32:725-731

16. Yeo SC, Liew A, Barratt J (2015) Emerging therapies in immunoglobulin a nephropathy. Nephrology 20:788-800

17. Moldoveanu Z, Wyatt RJ, Lee JY, Tomana M, Julian BA, Mestecky J, Huang WQ, Anreddy SR, Hall S, Hastings MC, Lau KK, Cook WJ, Novak J (2007) Patients with IgA nephropathy have increased serum galactose-deficient IgA1 levels. Kidney Int 71:1148-1154

18. Allen AC, Bailey EM, Brenchley PE, Buck KS, Barratt J, Feehally $\mathrm{J}$ (2001) Mesangial IgA1 in IgA nephropathy exhibits aberrant $O$ glycosylation: observations in three patients. Kidney Int 60:969973

19. Allen AC, Bailey EM, Barratt J, Buck KS, Feehally J (1999) Analysis of IgA1 $O$-glycans in IgA nephropathy by fluorophoreassisted carbohydrate electrophoresis. J Am Soc Nephrol 10: 1763-1771

20. Hiki Y, Odani H, Takahashi M, Yasuda Y, Nishimoto A, Iwase H, Shinzato T, Kobayashi Y, Maeda K (2001) Mass spectrometry proves under- $O$-glycosylation of glomerular IgA1 in IgA nephropathy. Kidney Int 59:1077-1085

21. Coppo R, Amore A (2004) Aberrant glycosylation in IgA nephropathy (IgAN). Kidney Int 65:1544-1547

22. Xu LX, Zhao MH (2005) Aberrantly glycosylated serum IgA1 are closely associated with pathologic phenotypes of IgA nephropathy. Kidney Int 68:167-172

23. Woof JM, Russell MW (2011) Structure and function relationships in IgA. Mucosal Immunol 4:590-597

24. Suzuki H, Moldoveanu Z, Hall S, Brown R, Vu HL, Novak L, Julian BA, Tomana M, Wyatt RJ, Edberg JC, Alarcon GS, Kimberly RP, Tomino Y, Mestecky J, Novak J (2008) IgA1secreting cell lines from patients with IgA nephropathy produce aberrantly glycosylated IgA1. J Clin Invest 118:629-639

25. Raska M, Moldoveanu Z, Suzuki H, Brown R, Kulhavy R, Andrasi J, Hall S, Vu HL, Carlsson F, Lindahl G, Tomana M,
Julian BA, Wyatt RJ, Mestecky J, Novak J (2007) Identification and characterization of CMP-NeuAc:GalNAc-IgA1 alpha2,6sialyltransferase in IgA1-producing cells. J Mol Biol 369:69-78

26. Franc V, Rehulka P, Raus M, Stulik J, Novak J, Renfrow MB, Sebela M (2013) Elucidating heterogeneity of IgA1 hinge-region $O$-glycosylation by use of MALDI-TOF/TOF mass spectrometry: role of cysteine alkylation during sample processing. J Proteome 92:299-312

27. Yasutake J, Suzuki Y, Suzuki H, Hiura N, Yanagawa H, Makita Y, Kaneko E, Tomino Y (2015) Novel lectin-independent approach to detect galactose-deficient IgA1 in IgA nephropathy. Nephrol Dial Transplant 30:1315-1321

28. Yamada K, Kobayashi N, Ikeda T, Suzuki Y, Tsuge T, Horikoshi S, Emancipator SN, Tomino Y (2010) Down-regulation of core 1 beta1,3-galactosyltransferase and Cosmc by Th2 cytokine alters $O$-glycosylation of IgA1. Nephrol Dial Transplant 25:3890-3897

29. Li GS, Zhang H, Lv JC, Shen Y, Wang HY (2007) Variants of C1GALT1 gene are associated with the genetic susceptibility to IgA nephropathy. Kidney Int 71:448-453

30. Inoue $\mathrm{T}$, Sugiyama $\mathrm{H}$, Kikumoto $\mathrm{Y}$, Fukuoka N, Maeshima $\mathrm{Y}$, Hattori H, Fukushima K, Nishizaki K, Hiki Y, Makino H (2007) Downregulation of the beta1,3- galactosyltransferase gene in tonsillar B lymphocytes and aberrant lectin bindings to tonsillar IgA as a pathogenesis of IgA nephropathy. Contrib Nephrol 157:120 124

31. Smith AC, de Wolff JF, Molyneux K, Feehally J, Barratt J (2006) $O$-glycosylation of serum IgD in IgA nephropathy. J Am Soc Nephrol 17:1192-1199

32. Zhao N, Hou P, Lv J, Moldoveanu Z, Li Y, Kiryluk K, Gharavi AG, Novak J, Zhang H (2012) The level of galactose-deficient IgAl in the sera of patients with IgA nephropathy is associated with disease progression. Kidney Int 82:790-796

33. Lomax-Browne HJ, Visconti A, Pusey CD, Cook HT, Spector TD, Pickering MC, Falchi M (2017) IgA1 glycosylation is heritable in healthy twins. J Am Soc Nephrol 28:64-68

34. Hastings MC, Moldoveanu Z, Julian BA, Novak J, Sanders JT, McGlothan KR, Gharavi AG, Wyatt RJ (2010) Galactosedeficient IgA1 in African Americans with IgA nephropathy: serum levels and heritability. Clin J Am Soc Nephrol 5:2069-2074

35. Gharavi AG, Moldoveanu Z, Wyatt RJ, Barker CV, Woodford SY, Lifton RP, Mestecky J, Novak J, Julian BA (2008) Aberrant IgA1 glycosylation is inherited in familial and sporadic IgA nephropathy. J Am Soc Nephrol 19:1008-1014

36. Kiryluk K, Moldoveanu Z, Sanders JT, Eison TM, Suzuki H, Julian BA, Novak J, Gharavi AG, Wyatt RJ (2011) Aberrant glycosylation of IgA1 is inherited in both pediatric IgA nephropathy and Henoch-Schönlein purpura nephritis. Kidney Int 80:79-87

37. Lin X, Ding J, Zhu L, Shi S, Jiang L, Zhao M, Zhang H (2009) Aberrant galactosylation of IgA1 is involved in the genetic susceptibility of Chinese patients with IgA nephropathy. Nephrol Dial Transplant 24:3372-3375

38. Gale DP, Molyneux K, Wimbury D, Higgins P, Levine AP, Caplin B, Ferlin A, Yin P, Nelson CP, Stanescu H, Samani NJ, Kleta R, Yu X, Barratt J (2017) Galactosylation of IgA1 is associated with common variation in C1GALT1. J Am Soc Nephrol

39. Kiryluk K, Li Y, Moldoveanu Z, Suzuki H, Reily C, Hou P, Xie J, Mladkova N, Prakash S, Fischman C, Shapiro S, LeDesma RA, Bradbury D, Ionita-Laza I, Eitner F, Rauen T, Maillard N, Berthoux F, Floege J, Chen N, Zhang H, Scolari F, Wyatt RJ, Julian BA, Gharavi AG, Novak J (2017) GWAS for serum galactose-deficient IgA1 implicates critical genes of the $O$-glycosylation pathway. PLoS Genet 13:e1006609

40. Serino G, Sallustio F, Cox SN, Pesce F, Schena FP (2012) Abnormal miR-148b expression promotes aberrant glycosylation of IgA1 in IgA nephropathy. J Am Soc Nephrol 23:814-824 
41. Feehally J, Beattie TJ, Brenchley PE, Coupes BM, Mallick NP, Postlethwaite RJ (1986) Sequential study of the IgA system in relapsing IgA nephropathy. Kidney Int 30:924-931

42. Conley ME, Cooper MD, Michael AF (1980) Selective deposition of immunoglobulin A1 in immunoglobulin a nephropathy, anaphylactoid purpura nephritis, and systemic lupus erythematosus. J Clin Invest 66:1432-1436

43. Layward L, Allen AC, Hattersley JM, Harper SJ, Feehally J (1994) Low antibody affinity restricted to the IgA isotype in IgA nephropathy. Clin Exp Immunol 95:35-41

44. Gharavi AG, Kiryluk K, Choi M, Li Y, Hou P, Xie J, SannaCherchi S, Men CJ, Julian BA, Wyatt RJ, Novak J, He JC, Wang H, Lv J, Zhu L, Wang W, Wang Z, Yasuno K, Gunel M, Mane S, Umlauf S, Tikhonova I, Beerman I, Savoldi S, Magistroni R, Ghiggeri GM, Bodria M, Lugani F, Ravani P, Ponticelli C, Allegri L, Boscutti G, Frasca G, Amore A, Peruzzi L, Coppo R, Izzi C, Viola BF, Prati E, Salvadori M, Mignani R, Gesualdo L, Bertinetto F, Mesiano P, Amoroso A, Scolari F, Chen N, Zhang H, Lifton RP (2011) Genome-wide association study identifies susceptibility loci for IgA nephropathy. Nat Genet 43: 321-327

45. Harper SJ, Pringle JH, Wicks AC, Hattersley J, Layward L, Allen A, Gillies A, Lauder I, Feehally J (1994) Expression of J chain mRNA in duodenal IgA plasma cells in IgA nephropathy. Kidney Int 45:836-844

46. Harper SJ, Allen AC, Pringle JH, Feehally J (1996) Increased dimeric IgA producing B cells in the bone marrow in IgA nephropathy determined by in situ hybridisation for $\mathrm{J}$ chain mRNA. J Clin Pathol 49:38-42

47. Batra A, Smith AC, Feehally J, Barratt J (2007) T-cell homing receptor expression in IgA nephropathy. Nephrol Dial Transplant $22: 2540-2548$

48. Buren M, Yamashita M, Suzuki Y, Tomino Y, Emancipator SN (2007) Altered expression of lymphocyte homing chemokines in the pathogenesis of IgA nephropathy. Contrib Nephrol 157:50-55

49. Kennel-de March A, Bene MC, Renoult E, Kessler M, Faure GC, Kolopp-Sarda MN (1999) Enhanced expression of L-selectin on peripheral blood lymphocytes from patients with IgA nephropathy. Clin Exp Immunol 115:542-546

50. Kennel-De March A, Bene MC, Hurault de Ligny B, Kessler M, Faure GC (1997) Enhanced expression of CD31 and CD54 on tonsillar high endothelial venules in IgA nephropathy. Clin Immunol Immunopathol 84:158-165

51. Smith AC, Molyneux K, Feehally J, Barratt J (2006) O-glycosylation of serum IgA1 antibodies against mucosal and systemic antigens in IgA nephropathy. J Am Soc Nephrol 17:3520-3528

52. Barratt J, Bailey EM, Buck KS, Mailley J, Moayyedi P, Feehally J, Turney JH, Crabtree JE, Allen AC (1999) Exaggerated systemic antibody response to mucosal Helicobacter pylori infection in IgA nephropathy. Am J Kidney Dis 33:1049-1057

53. Leinikki PO, Mustonen J, Pasternack A (1987) Immune response to oral polio vaccine in patients with IgA glomerulonephritis. Clin Exp Immunol 68:33-38

54. Ots M, Uibo O, Metskula K, Uibo R, Salupere V (1999) IgAantigliadin antibodies in patients with IgA nephropathy: the secondary phenomenon? Am J Nephrol 19:453-458

55. Feehally J, Beattie TJ, Brenchley PE, Coupes BM, Mallick NP, Postlethwaite RJ (1987) Response of circulating immune complexes to food challenge in relapsing IgA nephropathy. Pediatr Nephrol 1:581-586

56. Kennel A, Bene MC, Hurault de Ligny B, Kessler M, Faure G (1995) Serum anti-dextran antibodies in IgA nephropathy. Clin Nephrol 43:216-220

57. Floege J, Feehally $\mathbf{J}$ (2016) The mucosa-kidney axis in IgA nephropathy. Nat Rev Nephrol 12:147-156
58. Coppo R (2017) The gut-kidney axis in IgA nephropathy: role of microbiota and diet on genetic predisposition. Pediatr Nephrol. doi:10.1007/s00467-017-3652-1

59. Coppo R, Mazzucco G, Martina G, Roccatello D, Amore A, Novara R, Bargoni A, Piccoli G, Sena LM (1989) Gluteninduced experimental IgA glomerulopathy. Lab Investig 60:499506

60. Papista C, Lechner S, Ben Mkaddem S, LeStang MB, Abbad L, Bex-Coudrat J, Pillebout E, Chemouny JM, Jablonski M, Flamant M, Daugas E, Vrtovsnik F, Yiangou M, Berthelot L, Monteiro RC (2015) Gluten exacerbates IgA nephropathy in humanized mice through gliadin-CD89 interaction. Kidney Int 88:276-285

61. Coppo R, Amore A, Roccatello D (1992) Dietary antigens and primary immunoglobulin a nephropathy. J Am Soc Nephrol 2: S173-S180

62. Suzuki H, Suzuki Y, Narita I, Aizawa M, Kihara M, Yamanaka T, Kanou T, Tsukaguchi H, Novak J, Horikoshi S, Tomino Y (2008) Toll-like receptor 9 affects severity of IgA nephropathy. J Am Soc Nephrol 19:2384-2395

63. Takeda K, Kaisho T, Akira S (2003) Toll-like receptors. Annu Rev Immunol 21:335-376

64. Akira S (2003) Mammalian Toll-like receptors. Curr Opin Immunol 15:5-11

65. Park HJ, Hahn WH, Suh JS, Kim MJ, Kang SW, Lee JS, Kim JW, Chung JH, Cho BS (2011) Association between Toll-like receptor 10 (TLR10) gene polymorphisms and childhood IgA nephropathy. Eur J Pediatr 170:503-509

66. Qin W, Zhong X, Fan JM, Zhang YJ, Liu XR, Ma XY (2008) External suppression causes the low expression of the Cosmc gene in IgA nephropathy. Nephrol Dial Transplant 23:1608-1614

67. Donadio ME, Loiacono E, Peruzzi L, Amore A, Camilla R, Chiale F, Vergano L, Boido A, Conrieri M, Bianciotto M, Bosetti FM, Coppo R (2014) Toll-like receptors, immunoproteasome and regulatory $\mathrm{T}$ cells in children with Henoch-Schönlein purpura and primary IgA nephropathy. Pediatr Nephrol 29:1545-1551

68. Blaas SH, Stieber-Gunckel M, Falk W, Obermeier F, Rogler G (2009) CpG-oligodeoxynucleotides stimulate immunoglobulin A secretion in intestinal mucosal B cells. Clin Exp Immunol 155: 534-540

69. Zhai YL, Zhu L, Shi SF, Liu LJ, Lv JC, Zhang H (2016) Increased APRIL expression induces IgA1 aberrant glycosylation in IgA nephropathy. Medicine (Baltimore) 95:e3099

70. Bosello S, Youinou P, Daridon C, Tolusso B, Bendaoud B, Pietrapertosa D, Morelli A, Ferraccioli G (2008) Concentrations of BAFF correlate with autoantibody levels, clinical disease activity, and response to treatment in early rheumatoid arthritis. J Rheumatol 35:1256-1264

71. Groom J, Kalled SL, Cutler AH, Olson C, Woodcock SA, Schneider P, Tschopp J, Cachero TG, Batten M, Wheway J, Mauri D, Cavill D, Gordon TP, Mackay CR, Mackay F (2002) Association of BAFF/BLyS overexpression and altered B cell differentiation with Sjögren's syndrome. J Clin Invest 109:59-68

72. Mackay IR, Groom J, Mackay CR (2002) Levels of BAFF in serum in primary biliary cirrhosis and autoimmune diabetes. Autoimmunity 35:551-553

73. Mariette X, Roux S, Zhang J, Bengoufa D, Lavie F, Zhou T, Kimberly R (2003) The level of BLyS (BAFF) correlates with the titre of autoantibodies in human Sjögren's syndrome. Ann Rheum Dis 62:168-171

74. Cheema GS, Roschke V, Hilbert DM, Stohl W (2001) Elevated serum B lymphocyte stimulator levels in patients with systemic immune-based rheumatic diseases. Arthritis Rheum 44:13131319

75. McCarthy DD, Kujawa J, Wilson C, Papandile A, Poreci U, Porfilio EA, Ward L, Lawson MA, Macpherson AJ, McCoy 
KD, Pei Y, Novak L, Lee JY, Julian BA, Novak J, Ranger A, Gommerman JL, Browning JL (2011) Mice overexpressing BAFF develop a commensal flora-dependent, IgA-associated nephropathy. J Clin Invest 121:3991-4002

76. Xin G, Shi W, Xu LX, Su Y, Yan LJ, Li KS (2013) Serum BAFF is elevated in patients with IgA nephropathy and associated with clinical and histopathological features. J Nephrol 26:683-690

77. Goto T, Bandoh N, Yoshizaki T, Nozawa H, Takahara M, Ueda S, Hayashi T, Harabuchi Y (2008) Increase in B-cell-activation factor (BAFF) and IFN-gamma productions by tonsillar mononuclear cells stimulated with deoxycytidyl-deoxyguanosine oligodeoxynucleotides (CpG-ODN) in patients with IgA nephropathy. Clin Immunol 126:260-269

78. Kiryluk K, Li Y, Scolari F, Sanna-Cherchi S, Choi M, Verbitsky M, Fasel D, Lata S, Prakash S, Shapiro S, Fischman C, Snyder HJ, Appel G, Izzi C, Viola BF, Dallera N, Del Vecchio L, Barlassina C, Salvi E, Bertinetto FE, Amoroso A, Savoldi S, Rocchietti M, Amore A, Peruzzi L, Coppo R, Salvadori M, Ravani P, Magistroni R, Ghiggeri GM, Caridi G, Bodria M, Lugani F, Allegri L, Delsante M, Maiorana M, Magnano A, Frasca G, Boer E, Boscutti G, Ponticelli C, Mignani R, Marcantoni C, Di Landro D, Santoro D, Pani A, Polci R, Feriozzi S, Chicca S, Galliani M, Gigante M, Gesualdo L, Zamboli P, Battaglia GG, Garozzo M, Maixnerova D, Tesar V, Eitner F, Rauen T, Floege J, Kovacs T, Nagy J, Mucha K, Paczek L, Zaniew M, MizerskaWasiak M, Roszkowska-Blaim M, Pawlaczyk K, Gale D, Barratt J, Thibaudin L, Berthoux F, Canaud G, Boland A, Metzger M, Panzer U, Suzuki H, Goto S, Narita I, Caliskan Y, Xie J, Hou P, Chen N, Zhang H, Wyatt RJ, Novak J, Julian BA, Feehally J, Stengel B, Cusi D, Lifton RP, Gharavi AG (2014) Discovery of new risk loci for IgA nephropathy implicates genes involved in immunity against intestinal pathogens. Nat Genet 46:1187-1196

79. Muto M, Manfroi B, Suzuki H, Joh K, Nagai M, Wakai S, Righini C, Maiguma M, Izui S, Tomino Y, Huard B, Suzuki Y (2017) Tolllike receptor 9 stimulation induces aberrant expression of a proliferation-inducing ligand by tonsillar germinal center B cells in IgA nephropathy. J Am Soc Nephrol 28:1227-1238

80. Fellstrom BC, Barratt J, Cook H, Coppo R, Feehally J, de Fijter JW, Floege J, Hetzel G, Jardine AG, Locatelli F, Maes BD, Mercer A, Ortiz F, Praga M, Sorensen SS, Tesar V, Del Vecchio L, Investigators NT (2017) Targeted-release budesonide versus placebo in patients with IgA nephropathy (NEFIGAN): a doubleblind, randomised, placebo-controlled phase $2 \mathrm{~b}$ trial. Lancet. doi: 10.1016/S0140-6736(17)30550-0

81. Lafayette RA, Canetta PA, Rovin BH, Appel GB, Novak J, Nath KA, Sethi S, Tumlin JA, Mehta K, Hogan M, Erickson S, Julian BA, Leung N, Enders FT, Brown R, Knoppova B, Hall S, Fervenza FC (2017) A randomized, controlled trial of rituximab in IgA nephropathy with proteinuria and renal dysfunction. J Am Soc Nephrol 28:1306-1313

82. Kyburz D, Brentano F, Gay S (2006) Mode of action of hydroxychloroquine in RA-evidence of an inhibitory effect on toll-like receptor signaling. Nat Clin Pract Rheumatol 2:458-459

83. Ziegler HK, Unanue ER (1982) Decrease in macrophage antigen catabolism caused by ammonia and chloroquine is associated with inhibition of antigen presentation to T cells. Proc Natl Acad Sci U S A 79:175-178

84. Gao R, Wu W, Wen Y, Li X (2017) Hydroxychloroquine alleviates persistent proteinuria in IgA nephropathy. Int Urol Nephrol. doi: 10.1007/s11255-017-1574-2

85. Yanagihara T, Brown R, Hall S, Moldoveanu Z, Goepfert A, Tomana M, Julian BA, Mestecky J, Novak J (2012) In vitrogenerated immune complexes containing galactose-deficient IgA1 stimulate proliferation of mesangial cells. Results Immunol 2:166-172
86. Suzuki H, Fan R, Zhang Z, Brown R, Hall S, Julian BA, Chatham WW, Suzuki Y, Wyatt RJ, Moldoveanu Z, Lee JY, Robinson J, Tomana M, Tomino Y, Mestecky J, Novak J (2009) Aberrantly glycosylated IgA1 in IgA nephropathy patients is recognized by IgG antibodies with restricted heterogeneity. J Clin Invest 119: $1668-1677$

87. Kokubo T, Hiki Y, Iwase H, Horii A, Tanaka A, Nishikido J, Hotta K, Kobayashi Y (1997) Evidence for involvement of IgA1 hinge glycopeptide in the IgA1-IgA1 interaction in IgA nephropathy. J Am Soc Nephrol 8:915-919

88. Tomana M, Matousovic K, Julian BA, Radl J, Konecny K, Mestecky J (1997) Galactose-deficient IgA1 in sera of IgA nephropathy patients is present in complexes with IgG. Kidney Int 52:509-516

89. Yanagawa H, Suzuki H, Suzuki Y, Kiryluk K, Gharavi AG, Matsuoka K, Makita Y, Julian BA, Novak J, Tomino Y (2014) A panel of serum biomarkers differentiates IgA nephropathy from other renal diseases. PLoS One 9:e98081

90. Berthoux F, Suzuki H, Thibaudin L, Yanagawa H, Maillard N, Mariat C, Tomino Y, Julian BA, Novak J (2012) Autoantibodies targeting galactose-deficient $\operatorname{IgA} 1$ associate with progression of IgA nephropathy. J Am Soc Nephrol 23:1579-1587

91. Huang ZQ, Raska M, Stewart TJ, Reily C, King RG, Crossman DK, Crowley MR, Hargett A, Zhang Z, Suzuki H, Hall S, Wyatt RJ, Julian BA, Renfrow MB, Gharavi AG, Novak J (2016) Somatic mutations modulate autoantibodies against galactosedeficient IgA1 in IgA nephropathy. J Am Soc Nephrol 27:32783284

92. Feehally J, Farrall M, Boland A, Gale DP, Gut I, Heath S, Kumar A, Peden JF, Maxwell PH, Morris DL, Padmanabhan S, Vyse TJ, Zawadzka A, Rees AJ, Lathrop M, Ratcliffe PJ (2010) HLA has strongest association with IgA nephropathy in genome-wide analysis. J Am Soc Nephrol 21:1791-1797

93. Monteiro RC (2005) New insights in the pathogenesis of IgA nephropathy. Nefrologia 25(Suppl 2):82-86

94. Berthelot L, Papista C, Maciel TT, Biarnes-Pelicot M, Tissandie E, Wang PH, Tamouza H, Jamin A, Bex-Coudrat J, Gestin A, Boumediene A, Arcos-Fajardo M, England P, Pillebout E, Walker F, Daugas E, Vrtosvnik F, Flamant M, Benhamou M, Cogne M, Moura IC, Monteiro RC (2012) Transglutaminase is essential for IgA nephropathy development acting through IgA receptors. J Exp Med 209:793-806

95. Kanamaru Y, Blank U, Monteiro RC (2007) IgA Fc receptor I is a molecular switch that determines IgA activating or inhibitory functions. Contrib Nephrol 157:148-152

96. Kanamaru Y, Tamouza H, Pfirsch S, El-Mehdi D, GuerinMarchand C, Pretolani M, Blank U, Monteiro RC (2007) IgA Fc receptor I signals apoptosis through the FcRgamma ITAM and affects tumor growth. Blood 109:203-211

97. Berthelot L, Robert T, Vuiblet V, Tabary T, Braconnier A, Drame M, Toupance O, Rieu P, Monteiro RC, Toure F (2015) Recurrent IgA nephropathy is predicted by altered glycosylated IgA, autoantibodies and soluble CD89 complexes. Kidney Int 88:815-822

98. van der Boog PJ, De Fijter JW, Van Kooten C, Van Der Holst R, Van Seggelen A, Van Es LA, Daha MR (2003) Complexes of IgA with FcalphaRI/CD89 are not specific for primary IgA nephropathy. Kidney Int 63:514-521

99. Vuong MT, Hahn-Zoric M, Lundberg S, Gunnarsson I, van Kooten C, Wramner L, Seddighzadeh M, Fernstrom A, Hanson LA, Do LT, Jacobson SH, Padyukov L (2010) Association of soluble CD89 levels with disease progression but not susceptibility in IgA nephropathy. Kidney Int 78:1281-1287

100. Boyd JK, Barratt J (2010) Immune complex formation in IgA nephropathy: CD89 a 'saint' or a 'sinner'? Kidney Int 78:12111213 
101. Coppo R, Amore A, Gianoglio B, Reyna A, Peruzzi L, Roccatello D, Alessi D, Sena LM (1993) Serum IgA and macromolecular IgA reacting with mesangial matrix components. Contrib Nephrol 104: $162-171$

102. Kokubo T, Hiki Y, Iwase H, Tanaka A, Toma K, Hotta K, Kobayashi Y (1998) Protective role of IgA1 glycans against IgA1 self-aggregation and adhesion to extracellular matrix proteins. J Am Soc Nephrol 9:2048-2054

103. Working Group of the International Ig ANN, the Renal Pathology S, Cattran DC, Coppo R, Cook HT, Feehally J, Roberts IS, Troyanov S, Alpers CE, Amore A, Barratt J, Berthoux F, Bonsib S, Bruijn JA, D'Agati V, D'Amico G, Emancipator S, Emma F, Ferrario F, Fervenza FC, Florquin S, Fogo A, Geddes CC, Groene HJ, Haas M, Herzenberg AM, Hill PA, Hogg RJ, Hsu SI, Jennette JC, Joh K, Julian BA, Kawamura T, Lai FM, Leung CB, Li LS, Li PK, Liu ZH, Mackinnon B, Mezzano S, Schena FP, Tomino Y, Walker PD, Wang H, Weening JJ, Yoshikawa N, Zhang H (2009) The Oxford classification of IgA nephropathy: rationale, clinicopathological correlations, and classification. Kidney Int 76:534545

104. Trimarchi H, Barratt J, Cattran DC, Cook HT, Coppo R, Haas M, Liu ZH, Roberts IS, Yuzawa Y, Zhang H, Feehally J, Ig ANCWGotIINN, the Renal Pathology S, Conference P (2017) Oxford classification of IgA nephropathy 2016: an update from the IgA nephropathy classification working group. Kidney Int 91: 1014-1021

105. Lai KN, Leung JC, Chan LY, Saleem MA, Mathieson PW, Tam KY, Xiao J, Lai FM, Tang SC (2009) Podocyte injury induced by mesangial-derived cytokines in IgA nephropathy. Nephrol Dial Transplant 24:62-72

106. Hara M, Yanagihara T, Kihara I (2007) Cumulative excretion of urinary podocytes reflects disease progression in $\operatorname{IgA}$ nephropathy and Schönlein-Henoch purpura nephritis. Clin J Am Soc Nephrol 2:231-238

107. Wang C, Ye Z, Peng H, Tang H, Liu X, Chen Z, Yu X, Lou T (2009) Effect of aggregated immunoglobulin A1 from immunoglobulin a nephropathy patients on nephrin expression in podocytes. Nephrology 14:213-218

108. Lai KN, Leung JC, Chan LY, Saleem MA, Mathieson PW, Lai FM, Tang SC (2008) Activation of podocytes by mesangialderived TNF-alpha: glomerulo-podocytic communication in IgA nephropathy. Am J Physiol Renal Physiol 294:F945-F955

109. Chan LY, Leung JC, Tsang AW, Tang SC, Lai KN (2005) Activation of tubular epithelial cells by mesangial-derived TNFalpha: glomerulotubular communication in IgA nephropathy. Kidney Int 67:602-612

110. Coulon S, Dussiot M, Grapton D, Maciel TT, Wang PH, Callens C, Tiwari MK, Agarwal S, Fricot A, Vandekerckhove J, Tamouza H, Zermati Y, Ribeil JA, Djedaini K, Oruc Z, Pascal V, Courtois G, Arnulf B, Alyanakian MA, Mayeux P, Leanderson T, Benhamou M, Cogne M, Monteiro RC, Hermine O, Moura IC (2011) Polymeric IgA1 controls erythroblast proliferation and accelerates erythropoiesis recovery in anemia. Nat Med 17:1456-1465

111. Moura IC, Centelles MN, Arcos-Fajardo M, Malheiros DM, Collawn JF, Cooper MD, Monteiro RC (2001) Identification of the transferrin receptor as a novel immunoglobulin (Ig)A1 receptor and its enhanced expression on mesangial cells in IgA nephropathy. J Exp Med 194:417-425

112. Moura IC, Arcos-Fajardo M, Gdoura A, Leroy V, Sadaka C, Mahlaoui N, Lepelletier Y, Vrtovsnik F, Haddad E, Benhamou M, Monteiro RC (2005) Engagement of transferrin receptor by polymeric IgA1: evidence for a positive feedback loop involving increased receptor expression and mesangial cell proliferation in IgA nephropathy. J Am Soc Nephrol 16:2667-2676
113. Lechner SM, Papista C, Chemouny JM, Berthelot L, Monteiro RC (2016) Role of IgA receptors in the pathogenesis of IgA nephropathy. J Nephrol 29:5-11

114. Leung JC, Tsang AW, Chan DT, Lai KN (2000) Absence of CD89, polymeric immunoglobulin receptor, and asialoglycoprotein receptor on human mesangial cells. J Am Soc Nephrol 11:241-249

115. Matousovic K, Novak J, Yanagihara T, Tomana M, Moldoveanu Z, Kulhavy R, Julian BA, Konecny K, Mestecky J (2006) IgAcontaining immune complexes in the urine of IgA nephropathy patients. Nephrol Dial Transplant: Off Publ Eur Dial Transplant Assoc - Eur Renal Assoc 21:2478-2484

116. McAdoo SP, Bhangal G, Page T, Cook HT, Pusey CD, Tam FW (2015) Correlation of disease activity in proliferative glomerulonephritis with glomerular spleen tyrosine kinase expression. Kidney Int 88:52-60

117. Smith J, McDaid JP, Bhangal G, Chawanasuntorapoj R, Masuda ES, Cook HT, Pusey CD, Tam FW (2010) A spleen tyrosine kinase inhibitor reduces the severity of established glomerulonephritis. J Am Soc Nephrol 21:231-236

118. McAdoo SP, Reynolds J, Bhangal G, Smith J, McDaid JP, Tanna A, Jackson WD, Masuda ES, Cook HT, Pusey CD, Tam FW (2014) Spleen tyrosine kinase inhibition attenuates autoantibody production and reverses experimental autoimmune GN. J Am Soc Nephrol 25:2291-2302

119. Kim MJ, Schaub S, Molyneux K, Koller MT, Stampf S, Barratt J (2016) Effect of immunosuppressive drugs on the changes of serum galactose-deficient $\operatorname{IgA} 1$ in patients with $\operatorname{IgA}$ nephropathy. PLoS One 11:e0166830

120. Maillard N, Wyatt RJ, Julian BA, Kiryluk K, Gharavi A, Fremeaux-Bacchi V, Novak J (2015) Current understanding of the role of complement in IgA nephropathy. J Am Soc Nephrol 26:1503-1512

121. Miyazaki R, Kuroda M, Akiyama T, Otani I, Tofuku Y, Takeda R (1984) Glomerular deposition and serum levels of complement control proteins in patients with IgA nephropathy. Clin Nephrol 21:335-340

122. Rauterberg EW, Lieberknecht HM, Wingen AM, Ritz E (1987) Complement membrane attack (MAC) in idiopathic IgA-glomerulonephritis. Kidney Int 31:820-829

123. Endo M, Ohi H, Ohsawa I, Fujita T, Matsushita M, Fujita T (1998) Glomerular deposition of mannose-binding lectin (MBL) indicates a novel mechanism of complement activation in IgA nephropathy. Nephrol Dial Transplant 13:1984-1990

124. Hisano S, Matsushita M, Fujita T, Endo Y, Takebayashi S (2001) Mesangial IgA2 deposits and lectin pathway-mediated complement activation in IgA glomerulonephritis. Am J Kidney Dis 38: $1082-1088$

125. Matsuda M, Shikata K, Wada J, Sugimoto H, Shikata Y, Kawasaki T, Makino H (1998) Deposition of mannan binding protein and mannan binding protein-mediated complement activation in the glomeruli of patients with IgA nephropathy. Nephron 80:408-413

126. Maeng YI, Kim MK, Park JB, Cho CH, Oh HK, Sung WJ, Park KK (2013) Glomerular and tubular C4d depositions in IgA nephropathy: relations with histopathology and with albuminuria. Int J Clin Exp Pathol 6:904-910

127. Espinosa M, Ortega R, Gomez-Carrasco JM, Lopez-Rubio F, Lopez-Andreu M, Lopez-Oliva MO, Aljama P (2009) Mesangial C4d deposition: a new prognostic factor in IgA nephropathy. Nephrol Dial Transplant 24:886-891

128. Espinosa M, Ortega R, Sanchez M, Segarra A, Salcedo MT, Gonzalez F, Camacho R, Valdivia MA, Cabrera R, Lopez K, Pinedo F, Gutierrez E, Valera A, Leon M, Cobo MA, Rodriguez R, Ballarin J, Arce Y, Garcia B, Munoz MD, Praga M, Spanish Group for Study of Glomerular D (2014) Association of C4d deposition with clinical outcomes in IgA nephropathy. Clin J Am Soc Nephrol 9:897-904 
129. Roos A, Rastaldi MP, Calvaresi N, Oortwijn BD, Schlagwein N, van Gijlswijk-Janssen DJ, Stahl GL, Matsushita M, Fujita T, van Kooten C, Daha MR (2006) Glomerular activation of the lectin pathway of complement in IgA nephropathy is associated with more severe renal disease. J Am Soc Nephrol 17:1724-1734

130. Zhu L, Zhai YL, Wang FM, Hou P, Lv JC, Xu DM, Shi SF, Liu LJ, Yu F, Zhao MH, Novak J, Gharavi AG, Zhang H (2015) Variants in complement factor $\mathrm{H}$ and complement factor $\mathrm{H}$-related protein genes, CFHR3 and CFHR1, affect complement activation in IgA nephropathy. J Am Soc Nephrol 26:1195-1204
131. Xie J, Kiryluk K, Li Y, Mladkova N, Zhu L, Hou P, Ren H, Wang W, Zhang H, Chen N, Gharavi AG (2016) Fine mapping implicates a deletion of CFHR1 and CFHR3 in protection from IgA nephropathy in Han Chinese. J Am Soc Nephrol 27:31873194

132. Ring T, Pedersen BB, Salkus G, Goodship TH (2015) Use of eculizumab in crescentic IgA nephropathy: proof of principle and conundrum? Clin Kidney J 8:489-491

133. Rosenblad T, Rebetz J, Johansson M, Bekassy Z, Sartz L, Karpman D (2014) Eculizumab treatment for rescue of renal function in IgA nephropathy. Pediatr Nephrol 29:2225-2228 